\title{
Systemic review of the context of external financing of MSMEs in Mexico
}

\author{
Revisión sistémica del contexto del financiamiento externo de las Mipymes de México \\ JIMÉNEZ-RICO, Artemio†*, GUTIÉRREZ-RANGEL, Héctor Fabián and GALVÁN-ZAVALA, \\ Karina
}

Universidad de Guanajuato, División de Ciencias Económico-Administrativas, Guanajuato, Guanajuato, México.

ID $1^{\text {st }}$ Author: Artemio, Jiménez-Rico / ORC ID: 0000-0001-9069-6483, Researcher ID Thomson: S-7880-2018, CVU CONACYT ID: 947479

ID $1^{\text {st }}$ Coauthor: Héctor Fabián, Gutiérrez-Rangel / ORC ID: 0000-0001-6970-723X, Researcher ID Thomson: S-85142018, CVU CONACYT ID: 745113

ID $2^{\text {nd }}$ Coauthor: Karina, Galván-Zavala / ORC ID: 0000-0001-5759-8814, arXiv Author ID: 3066602, CVU CONACYT ID: 273545

DOI: $10.35429 / \mathrm{JBAB} \cdot 2021.8 .5 \cdot 12.22$

Received March 22, 2021; Accepted June 30, 2021

\begin{abstract}
MSMEs are a key component for the economic and social development of countries, in Mexico they generate approximately $70 \%$ of jobs and contribute around $35 \%$ of GDP. There is great empirical evidence that shows that the lack of financing affects the economic growth of companies. Microenterprises are those that face the most external financing restrictions and indicate that high interest rates are their main limitation for not accessing external financing, therefore, they are the most affected in their economic growth. The objective of this research is to carry out a systemic review of the context of external financing of MSMEs in Mexico. The results infer that it is urgent to implement adequate public policies to strengthen the financial system and facilitate access to external financing under the best conditions for MSMEs to improve their competitiveness and economic growth.
\end{abstract}

External financing, Economic growth, MSMEs

\begin{abstract}
Resumen
Las Mipymes son un componente clave para el desarrollo económico y social de los países, en México generan aproximadamente el $70 \%$ de empleos y aportan alrededor del $35 \%$ del PIB. Existe una gran evidencia empírica que demuestra que la falta de financiamiento afecta el crecimiento económico de las empresas. Las microempresas son las que enfrentan más restricciones de financiamiento externo e indican que las altas tasas de interés son su principal limitante para no acceder a financiamiento externo, por lo tanto, son las más afectadas en su crecimiento económico. El objetivo de esta investigación es realizar una revisión sistémica del contexto del financiamiento externo de las Mipymes de México. Los resultados infieren que es urgente la implementación de políticas públicas adecuadas para fortalecer el sistema financiero y facilitar el acceso al financiamiento externo en las mejores condiciones a las Mipymes para mejorar su competitividad y su crecimiento económico.
\end{abstract}

Financiamiento externo, Crecimiento económico, Mipymes

Citation: JIMÉNEZ-RICO, Artemio, GUTIÉRREZ-RANGEL, Héctor Fabián and GALVÁN-ZAVALA, Karina. Systemic review of the context of external financing of MSMEs in Mexico. Journal- Business Administration -Marketing; Accounting. 2021. 5-8: 12-22

\footnotetext{
* Correspondence to Author (a.jimenezrico@ugto.mx)

$\uparrow$ Researcher contributing as first author.
} 


\section{Introduction}

Micro, small and medium-sized enterprises (MSMEs) are recognized as a key component for the economic growth and social development of the countries because they comprise more than 99\% of formal companies in Latin America, generate $61 \%$ of jobs and contribute to the $25 \%$ of the GDP of this region (Dini and Stumpo, 2018). In this sense, when comparing the $25 \%$ of GDP generated by Latin American MSMEs against the $56 \%$ contributed by those of the European Union, we realize that these companies can improve their performance to be more competitive (Dini and Stumpo, 2018).

One of the main barriers that prevents improving competitiveness and affects the economic growth of MSMEs it isthe lack of financing and its high cost. Likewise, there is great empirical evidence that shows that the lack of financing affects the economic growth of companies and that the most affected are microenterprises.

Given the importance of MSMEs for the economy of the countries, it is of great relevance to find solutions to this problem of lack of financing and its high cost. Currently, the large initiatives of support programs for MSMEs, created by governments and cooperation organizations, are still scarce, isolated and their results are not as expected.

Therefore, the objective of this research is to carry out a systemic review of the context of external financing of MSMEs in Mexico. This study contributes to providing a broad perspective to redesign public policies for access to external financing to improve the competitiveness and growth of MSMEs.

\section{Literature review}

\subsection{MSMEs and their economic contribution}

The economic importance of MSMEs is because they comprise $99 \%$ of formal companies in Latin America, contribute $61 \%$ of employment and contribute $25 \%$ of the Gross Domestic Product (GDP) of this region, for this reason, they represent a key factor in the economic and social development of the countries in this region (Dini and Stumpo, 2018).
Table 1 shows that there is a very evident contrast in the proportion of companies, as well as in jobs between MSMEs and large companies. Microenterprises in Colombia are those with the highest share of jobs generated with $50.6 \%$, followed by Peru, Ecuador, and Mexico with $48.5 \%, 47.3 \%$ and $45.7 \%$, respectively. In contrast, in Brazil and Costa Rica, large companies are those that provide the most jobs with $58 \%$ and $56.13 \%$, respectively. In general, MSMEs in most countries are positioned as the main source of employment (Ferraz and Ramos, 2018).

\begin{tabular}{|l|r|r|r|r|r|r|}
\cline { 2 - 8 } \multicolumn{1}{c}{} & \multicolumn{4}{c}{ Companies (\%) } & \multicolumn{1}{c|}{ Job positions (\%) } \\
\hline Country & \multicolumn{1}{c}{ Micro } & \multicolumn{1}{c|}{ SMEs } & \multicolumn{1}{c|}{ Large } & \multicolumn{1}{c|}{ Micro } & \multicolumn{1}{l}{ SMEs } & Large \\
\hline Argentina & 69.7 & 28.4 & 1.9 & 11.5 & 39.6 & 48.9 \\
\hline Brazil & 90.1 & 9.3 & 0.6 & 13.7 & 28.3 & 58.0 \\
\hline Colombia & 96.4 & 3.5 & 0.1 & 50.6 & 30.3 & 19.1 \\
\hline $\begin{array}{l}\text { Costa } \\
\text { Rica }\end{array}$ & 68.0 & 29.3 & 2.7 & 8.4 & 35.5 & 56.1 \\
\hline Ecuador & 95.4 & 4.4 & 0.2 & 47.3 & 29.8 & 22.9 \\
\hline Mexico & 95.5 & 4.3 & 0.2 & 45.7 & 23.6 & 30.8 \\
\hline Peru & 94.5 & 4.9 & 0.6 & 48.5 & 19.2 & 32.4 \\
\hline
\end{tabular}

Table 1 Proportion of companies and jobs created in Latin American countries

Source: Own elaboration with data from Gonzales, Hommes and Mirmulstein (cited in Ferraz and Ramos, 2018)

Something similar happens in Mexico, according to data from the 2014 economic census, issued by the National Institute of Statistics and Geography (INEGI), microenterprises represent $95.4 \%$ of the total economic units in Mexico, small 3.6\%, mediumsized $0.8 \%$ and large companies $0.2 \%$. Regarding the total gross production, microcompanies contribute $9.8 \%$, small $9.5 \%$, medium-sized $16.6 \%$ and large companies $64.1 \%$.

Regarding the employed personnel, micro-enterprises employ $39.8 \%$ of the total jobs, small companies $15.1 \%$, medium-sized companies $16.3 \%$ and large companies $28.8 \%$. In total, MSMEs correspond to $99.8 \%$ of all companies, contribute $35.9 \%$ of total gross production and generate $71.2 \%$ of jobs, as shown in Graph 1 (INEGI, 2015). 


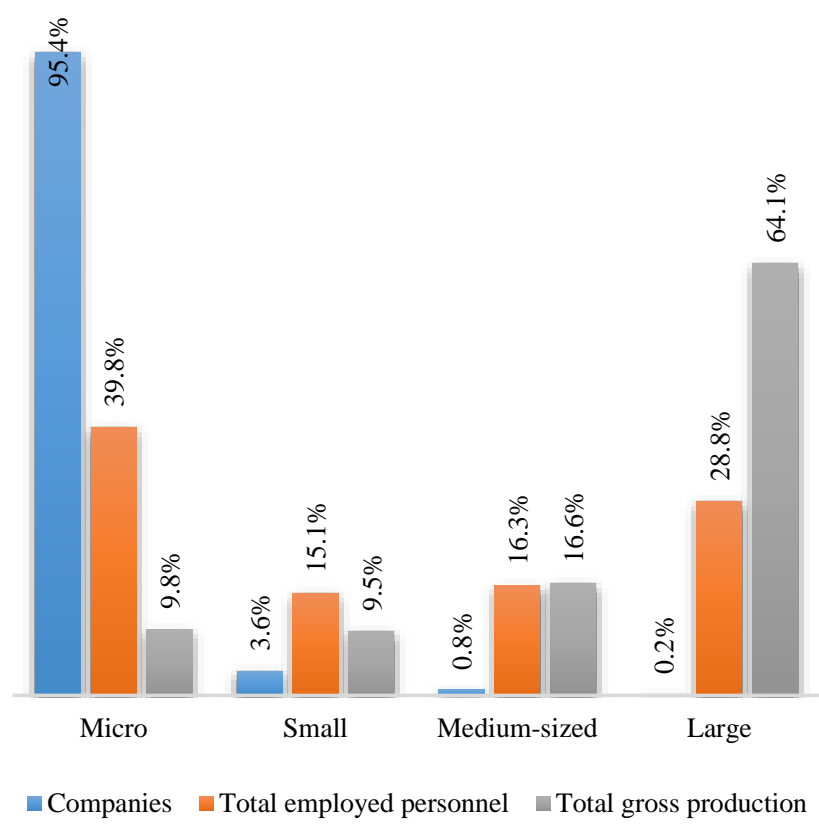

Graph 1 Distribution of companies, employed personnel and total gross production

Source: Own elaboration with data from economic censuses 2014, INEGI (2015)

\subsection{Impact of external financing on MSMEs}

Various studies show that, in both developed and developing countries, small companies that have less access to external financing are more limited in their operation and growth (Berger and Udell, 1998).

In this sense, Beck, Demirgüç - Kunt and Maksimovic (2005); Beck, Demirgüç-Kunt, Laeven and Maksimovic (2006) in their research confirmed that SMEs face greater obstacles to access to credit and high financing costs than large companies and that the magnitude of the impact of these obstacles on the growth of a company It is inversely related to the size of the company, with the smallest being the ones that are constantly more affected by these factors.

Demirgüç-Kunt, Love and Maksimovic (2006) showed that companies are more likely to prosper in countries with better access to external financing and better protection of investors, as well as to establish themselves as companies in countries with developed financial sectors and efficient legal systems, strong rights of shareholders and creditors, low corporate tax rates and few regulatory burdens because they face fewer financial, legal, and regulatory obstacles to their development.
In this sense, Beck and Demirgüc-Kunt (2006) point out that empirical studies show that financial and institutional development has a great impact on the economic growth of SMEs by reducing financial restrictions and increasing their access to formal sources of financing. This is also reflected in financing patterns, compared to large companies, small companies finance a lesser part of their investment and working capital with bank financing, while they finance a greater part with informal sources such as moneylenders, family, and friends.

Beck, Demirgüc-Kunt and MartínezPeria (2008, 2011) showed that the most significant differences in bank financing to companies are found between banks in developed and developing countries. Banks in developing countries tend not to favor SMEs, grant them a lower proportion of investment loans, charge them higher fees, as well as higher interest rates, compared to large companies.

According to De Mel, McKenzie and Woodruff (2008) and McKenzie and Woodruff (2008) increasing access to financing has confirmed to generate benefits for companies regardless of their size, however, the impact is usually greater in smaller companies. In the same sense, Beck, Demirgüc-Kunt and Honohan (2009) indicate that access to business financing allows companies to diversify their risks, increase their operations and invest in innovation. Bermudez and Bravo (2019) mention that a debt with vision and responsibility can be beneficial for MSMEs to obtain funds to improve their business competitiveness. However, according to data from the World Bank Enterprise Surveys, 28.9\% of companies in the world identify the lack of financing as their most important barrier to their growth, while in Mexico 29.6\% point out this limitation (CNBV, 2016 and CNBV, 2017).

According to the OECD, at the international level, business financing granted to MSMEs represents only $40 \%$ in countries with middle-income economies (OECD, 2019). There is a consensus in various studies that SMEs have severe problems of limited access to external financing through supply-side factors, largely due to the information asymmetry between SMEs and lenders or investors. Faced with this problem, most smaller companies prefer to resort to internal sources of financing such as accumulated and retained earnings (Xiang, Worthington, and Higgs, 2015).

JIMÉNEZ-RICO, Artemio, GUTIÉRREZ-RANGEL, Héctor Fabián and GALVÁN-ZAVALA, Karina. Systemic review of the context of external financing of MSMEs in Mexico. Journal- Business Administration -Marketing; Accounting. 2021 


\subsection{Determinants of external financing in MSMEs}

In accordance with Kumar, Sureka, and Colombage (2020), the capital structure of a company is the result of market conditions, the rationing of financing from funders, and the financial decision-making of the company. Studies on the capital structure of SMEs have gained great relevance in recent years due to the economic importance of these companies for the countries and because most research on capital structure has been carried out only in large companies.

Michaelas, Chittenden and Poutziouris (1999) in their research on the capital structure of UK SMEs, found that most of the determinants of capital structure presented by finance theory are relevant to small businesses. It is inferred that variables such as size, age, profitability, growth and future growth opportunities, operational risk, asset structure, stock turnover and net debt influence the level of debt at short and long term in small businesses. In addition, the results indicate that the capital structure of small companies depends on time and industry, the short-term average indebtedness ratios of SMEs tend to increase during periods of economic recession and to decrease as economic conditions improve in the market.

Watson and Wilson (2002) in their research empirically demonstrated some of the implications of the hierarchical order model using a sample of UK SMEs. One of the main implications of this model is that any hierarchical order will be positively related both to the common interests between the current owners and the managers or directors of the company, as well as to the degree of information asymmetry between internal and external. This implies that in practice decisions are made in companies for a financial structure consistent with a hierarchical order in which internal sources of financing will be preferred to external ones.

López-Gracia and Sogorb-Mira (2008) in their research on a sample of Spanish SMEs empirically tested two of the most important theories about financing in SMEs, the hierarchical order theory and the compensation theory.
The main results infer that both theories help to explain the capital structure of SMEs. However, despite finding clear evidence that SMEs follow a hierarchy of financing sources according to the hierarchical order model, the results highlight that there is greater confidence in SMEs that seek to achieve optimal leverage according to the model of compensation. Another important result is that both the size and the age of the companies are relevant factors in the financing of SMEs.

On the other hand, Xiang et al. (2015) in their research studied the effects of factors such as size, profitability, number of employees, business strategy and life cycle on the search for financing in Australian SMEs. Their results indicate that the lack of success in obtaining financing in the past continues to have a significant and cumulative impact on the behavior of seeking financing in the future. This situation and the capital rationing commonly observed in SMEs underestimates the real level of the problem, since many SMEs based on their bad experiences simply do not seek financing because they predict that they will be rejected. Bank financing can be affected by various factors, such as excessive documentation requirements; delays in evaluation processes; the high guarantees required, the high interest rates; ignorance of the instruments and products offered; the disinterest of some financial institutions; among others (Ferraz and Ramos, 2018).

Gómez, García and Marín (2009) found that interest rates are the main limitation when applying for a bank loan, followed by excess paperwork or the enormous amount of information required, commonly known as "banking bureaucracy" and thirdly there are the guarantees required by the banks. Likewise, mature (more than ten years) and medium-sized companies are more prone to credit approval. Additionally, it is relevant to have an endorsement with financial solvency. On the other hand, the lack of financing is linked to various factors such as the lack of guarantees, high transaction costs, insufficient development of alternative financial instruments, problems in the supply of credit from financial intermediaries, among others (Castillo, Figal, Maffioli and Ohaco, 2016). 
Another limitation of financing is the voluntary exclusion of access to credit, according to Zuleta (cited in Ferraz and Ramos, 2018) points out that it is very important to identify the reasons why this situation is created, because many companies consider that they do not need it, although they really do have a high financial dependence. One possible cause is the lack of financial knowledge, which makes it impossible for owners to perceive the need for financing. The requirements to access external financing represent obstacles in themselves for MSMEs because many of these companies are informal, that is, they do not have tax registration nor do they have real guarantees (Banco de México, 2015, cited in León and Saavedra, 2018).

Graph 2 shows that micro-enterprises indicated that the most important problem for which they consider that their businesses are not growing is the lack of credit with $22.7 \%$. In contrast, small and medium-sized companies only indicate this problem in $9.2 \%$ and $6 \%$ respectively (INEGI, 2016).

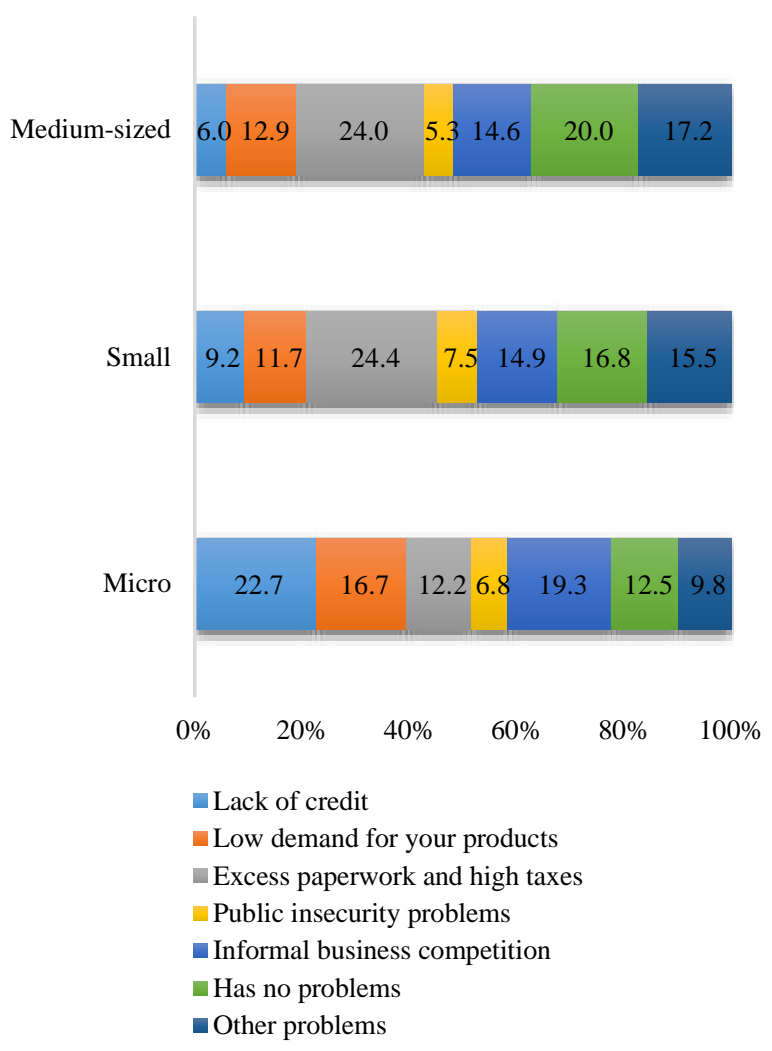

Graph 2 Main cause why they consider that their businesses are not growing

Source: Own elaboration with data from ENAPROCE 2015, INEGI (2016)
Despite this problem, Graph 3 shows that $60.1 \%$ of micro-enterprises, $52.6 \%$ of small ones, and $46.5 \%$ of medium-sized ones indicated that the main reason why they would not accept a bank loan is because they consider that they credits are very expensive.

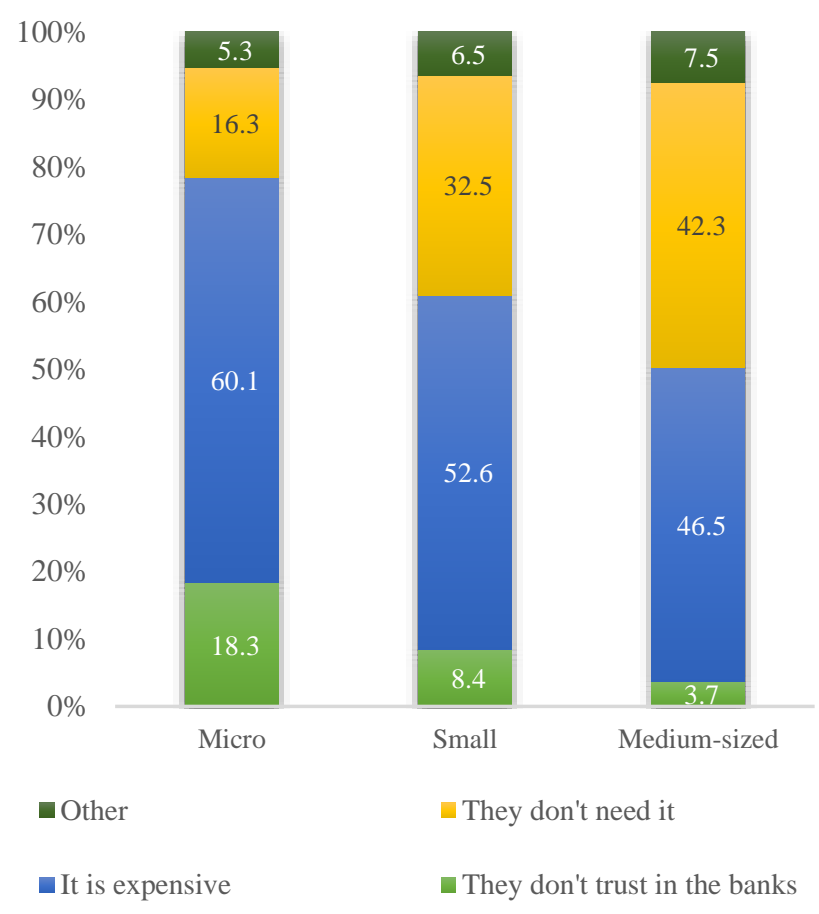

Graph 3 Main reasons why they would not accept a bank loan.

Source: Own elaboration with data from ENAPROCE 2015, INEGI (2016)

León and Saavedra (2018) indicate that credit to MSMEs in Mexico is widely more expensive than that of large companies. Micro and small businesses pay interest rates around three percentage points higher than mediumsized businesses. In this sense, according to data from Banco de México (2017), MSMEs must cover higher interest rates $(12.7 \%$ weighted average) than large companies (7.9\%). Likewise, the smaller the company, the higher the interest rate, which is why micro-companies have a weighted average rate of $14.5 \%$, small ones $12.2 \%$ and medium-sized ones $10.8 \%$.

\section{Methodology}

Due to its characteristics, the methodology used in this research corresponds to a qualitative approach with an exploratory scope. The technique used in this research was the collection and analysis of secondary data from the National Survey of Business Financing (ENAFIN) 2018, which was carried out jointly by the National Banking and Securities Commission (CNBV) and the National Institute of Statistics and Geography (INEGI).

JIMÉNEZ-RICO, Artemio, GUTIÉRREZ-RANGEL, Héctor Fabián and GALVÁN-ZAVALA, Karina. Systemic review of the context of external financing of MSMEs in Mexico. Journal- Business Administration -Marketing; Accounting. 2021 
The data collection instrument used in ENAFIN 2018 was a questionnaire made up of 75 questions divided into 4 sections:

1. Characteristics of the company - 22 questions.

2. Financing and loan applications - 28 questions.

3. Capital contributions and reserves - 7 questions.

4. Banking and financial services - 18 questions (CNBV, 2019).

The collection of information from ENAFIN 2018 was direct from the companies through a printed questionnaire or through the internet during the period from August 6 to October 5, 2018 (INEGI, 2019).

The target population of ENAFIN 2018 is made up of companies in Mexico that have six or more employed persons (micro, small, medium, and large), corresponding to the construction, manufacturing, trade and nonfinancial private services sectors, located in localities with 50,000 or more inhabitants (CNBV, 2019).

The sampling frame was made up of companies registered in the National Statistical Framework of Economic Units (MENUE), which is fed by the Statistical Business Registry of Mexico (RENEM) updated to the third quarter of 2017 (INEGI, 2019).

The sampling scheme used was probabilistic and stratified. For each company size, economic sector and locality size, a sample was calculated with a confidence level of $95 \%$ and a relative error of $10.8 \%$ for micro and small companies, $10 \%$ for medium and $9 \%$ for large companies. Therefore, ENAFIN 2018 is representative at the national level, by economic sector, company size, and locality size (INEGI, 2019). The original sample size was 4,188 companies. However, from the total original sample, information was obtained from $78.9 \%$ of the companies, so the information from the remaining $21.1 \%$ sample was not collected. Therefore, the final sample in which the complete information was collected was 3,296 companies, which represent a universe of 273,909 companies (CNBV, 2019).
The research design is non-experimental. In addition, the data used were collected from ENAFIN 2018, which was carried out from August 6 to October 5, 2018, for this reason it corresponds to a transectional or cross-sectional research design, because the data collection was carried out in a single moment or in a single time (Hernández-Sampieri and Mendoza, 2018).

Once the information was collected, the data was analyzed to carry out an exhaustive analysis of the context of the financing of MSMEs in Mexico and obtain greater objectivity in relation to the objective and the premises raised in this research.

\section{Results}

According to data from ENAFIN 2018, with respect to loan applications, the proportion of companies that requested financing decreased, in general, between 2016 and 2018. It is also confirmed that micro-businesses are those that made the least loan applications, while the medians are the ones that made the most credit applications, see Graph 4.

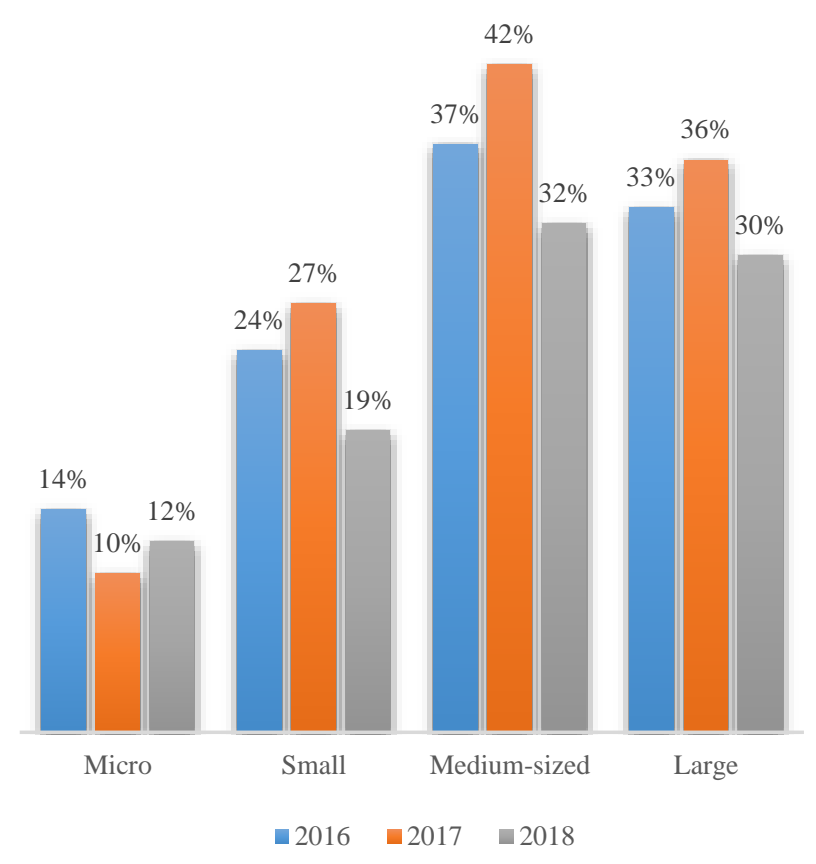

Graph 4 Percentage of companies that applied for credit. Source: Own elaboration [Excel] with data from ENAFIN 2018, CNBV (2019)

Regarding the companies that did grant them financing during 2017 and 2018, the microenterprises with the lowest percentage of financing stand out with $19.5 \%$ and $14.6 \%$, respectively; while the medians with the highest with $52.1 \%$ and $43.4 \%$, respectively. 
In general, there is a slight decrease in companies with financing from 2017 to 2018 , see Graph 5.

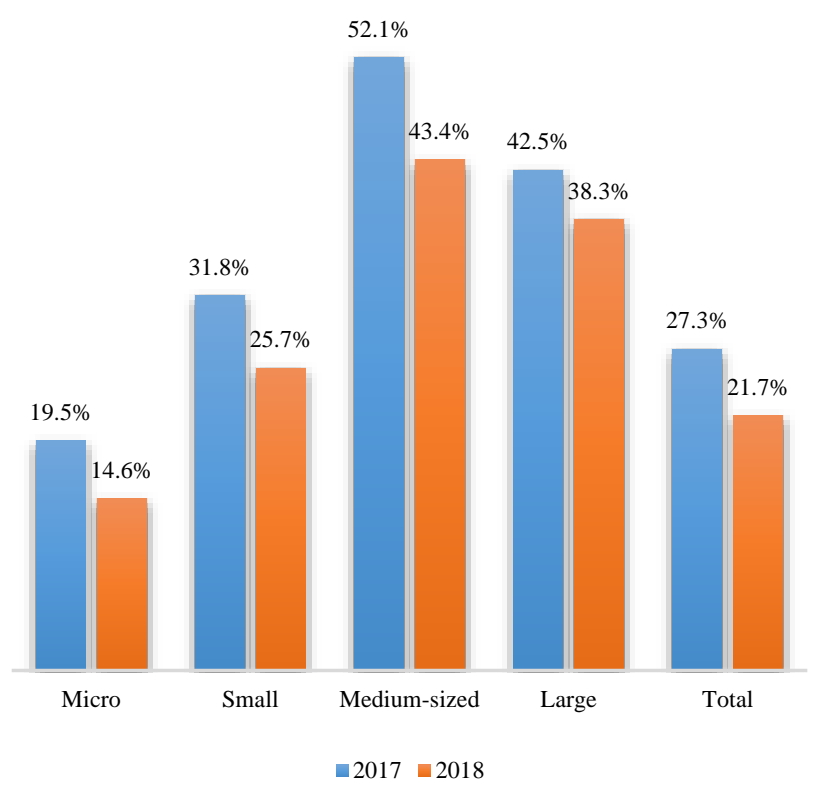

Graph 5 Companies with financing in 2017 and 2018. Source: Own elaboration [Excel] with data from ENAFIN 2018, INEGI (2019)

In relation to the sources of financing in 2018, it stands out that commercial banking was the main channel through which companies accessed credit with $75.4 \%$. Credits granted by suppliers represented the second most recurring source of financing with $30.4 \%$ and in third place is financing with family and friends with $11.7 \%$, as shown in Graph 6.

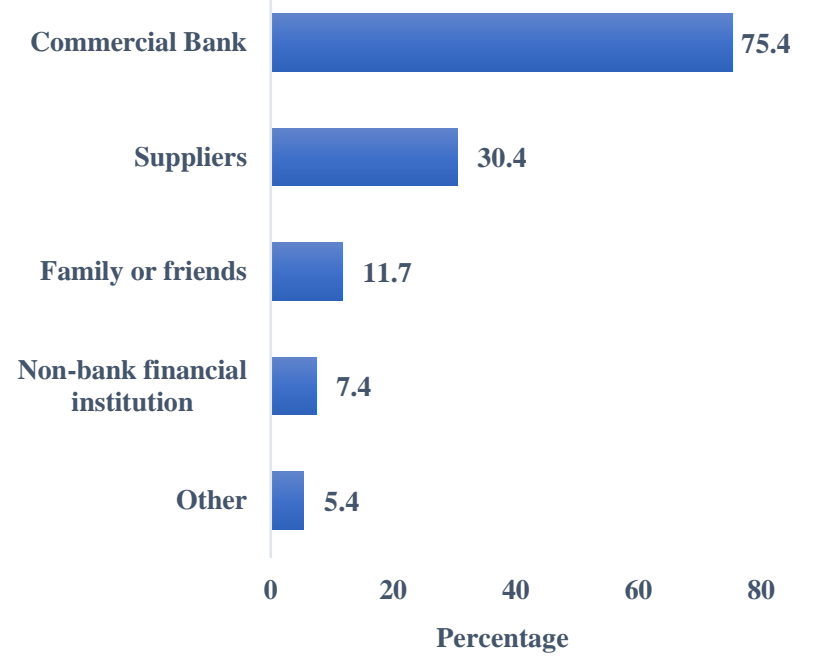

Graph 6 Financing sources in 2018.

Note: The percentages do not add up to 100 percent because companies may select more than one source. The Others option includes: Development banking, Government programs and Crowdfunding.

Source: Own elaboration [Excel] with data from ENAFIN 2018, INEGI (2019).
On the other hand, Graph 7 shows that in general, $27.8 \%$ of the companies that were rejected a loan in 2018 indicated that the lack of credit history was the main reason why they did not grant them financing. The same reason was also the main one indicated by micro-businesses with $47.3 \%$. On the contrary, $39.9 \%$ of large companies indicated that the most important reason for not receiving financing was due to low payment capacity.

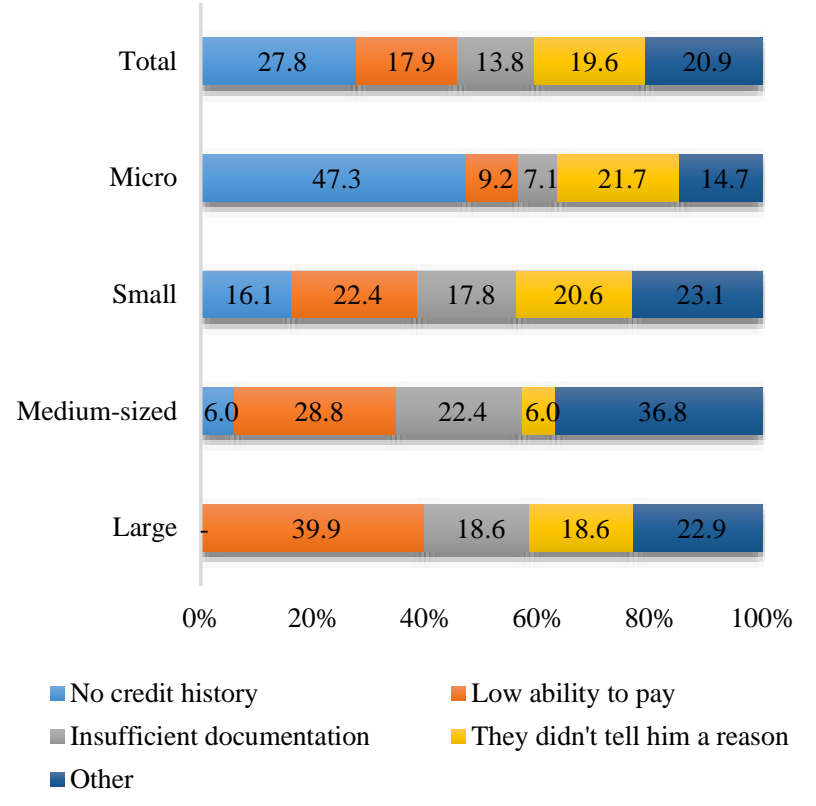

Graph 7 Main reason why they did not grant financing to companies, 2018.

Note: The "Other" option includes: Failed to prove income, No guarantee or collateral, Bad credit history, and Over-indebtedness.

Source: Own elaboration [Excel] with data from ENAFIN 2018, INEGI (2019).

Now, of the rejected credit applications, it is highlighted that in general $33.1 \%$ of the companies did not request any bank credit again, see detail in Graph 8. 


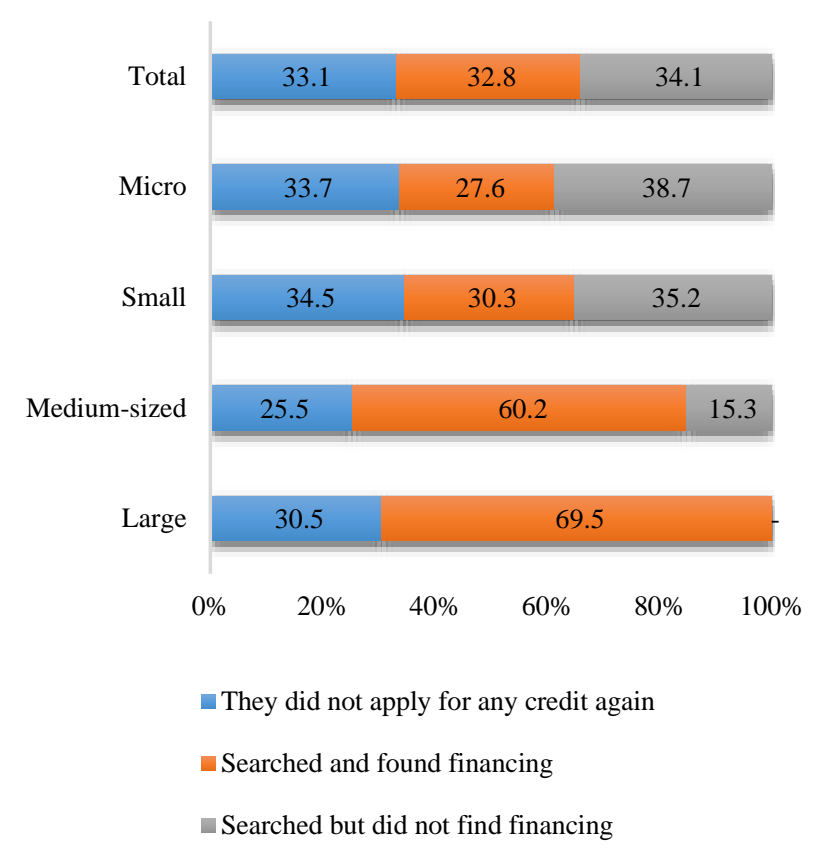

Graph 8 Action taken after credit rejection, 2018 Source: Own elaboration [Excel] with data from ENAFIN 2018, INEGI (2019).

Graph 9 shows a worrying situation, 54\% of companies have never requested or had financing since the beginning of their operations, this Graph is lower than the $60 \%$ reported in 2015. Again, micro-companies are the most affected, the $63 \%$ have never had or requested financing, in contrast to $31 \%$ of medium-sized companies and $43 \%$ of large companies.

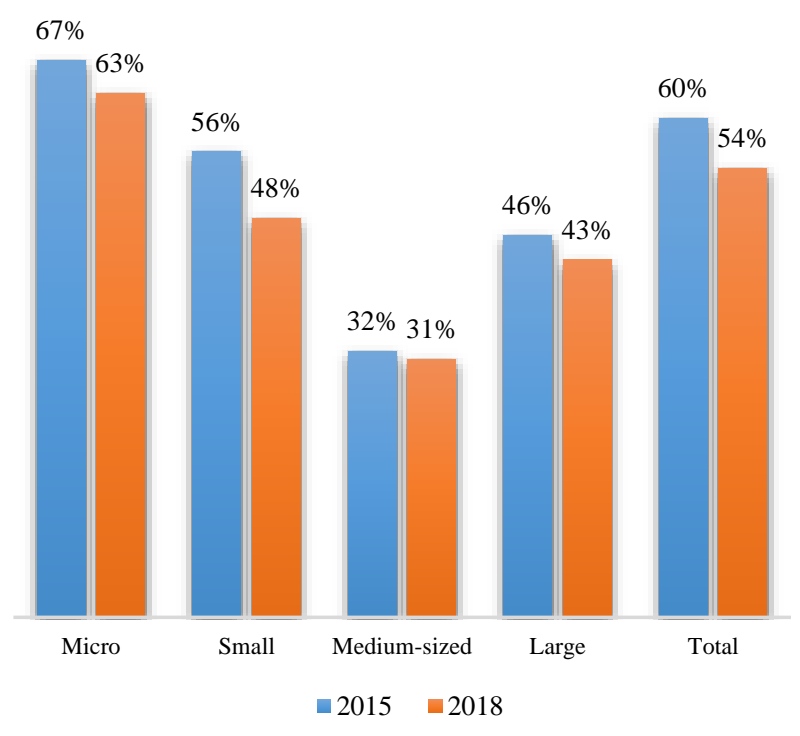

Graph 9 Companies that since the beginning of operations have never requested or had financing.

Source: Own elaboration [Excel] with data from ENAFIN 2018, CNBV (2019).
In this sense, Graph 10 shows the main factors that companies indicated as limiting access to credit, of which two stand out: "high interest" with $53.5 \%$, followed by those that indicated "many requirements" with $23.9 \%$.

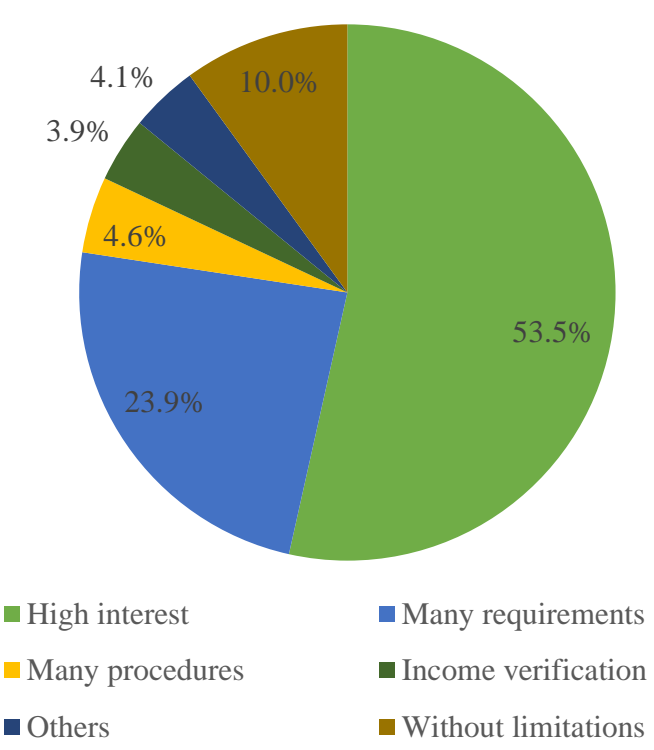

Graph 10 Main limitation of access to financing, 2018. Source: ENAFIN 2018, INEGI (2019).

In addition to the more popular sources of financing, there are other financial products, such as factoring and financial leasing. Graph 11 shows that financial factoring is used very little by companies, only $2 \%$ of all companies used it in 2018. Large companies are those that use this scheme most frequently with $7 \%$, while that micro-enterprises only use it $1 \%$.

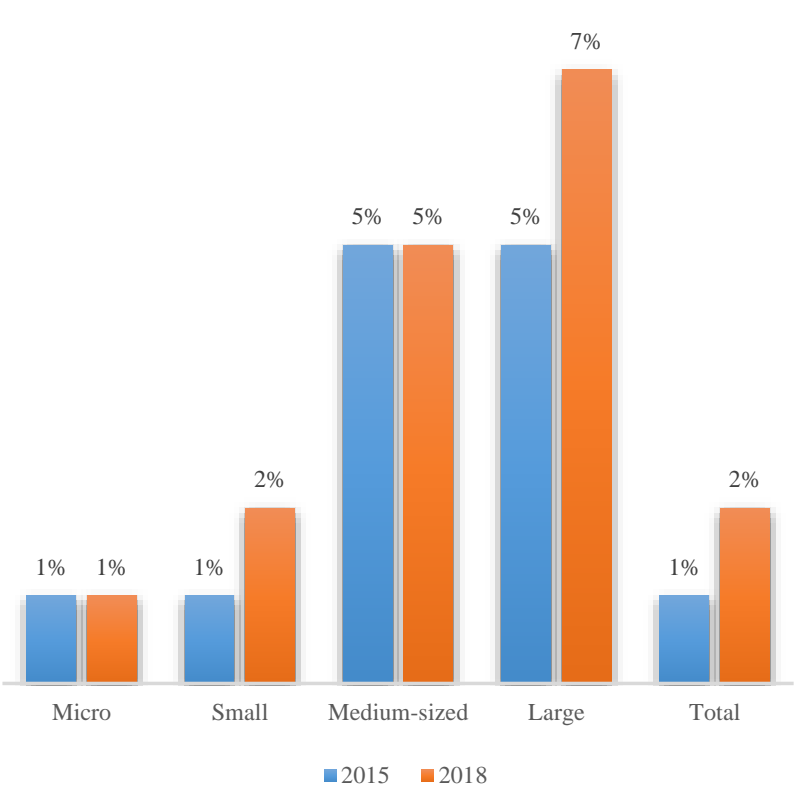

Graph 11 Companies that used financial factoring Source: ENAFIN 2018, CNBV (2019). 
On the other hand, Graph 12 shows that financial leasing is also little used, only $10 \%$ of all companies temporarily leased an asset in 2018. This proportion increases significantly with company size, while $5 \%$ of micro leased an asset in 2017, in large companies this activity increased to $26 \%$.

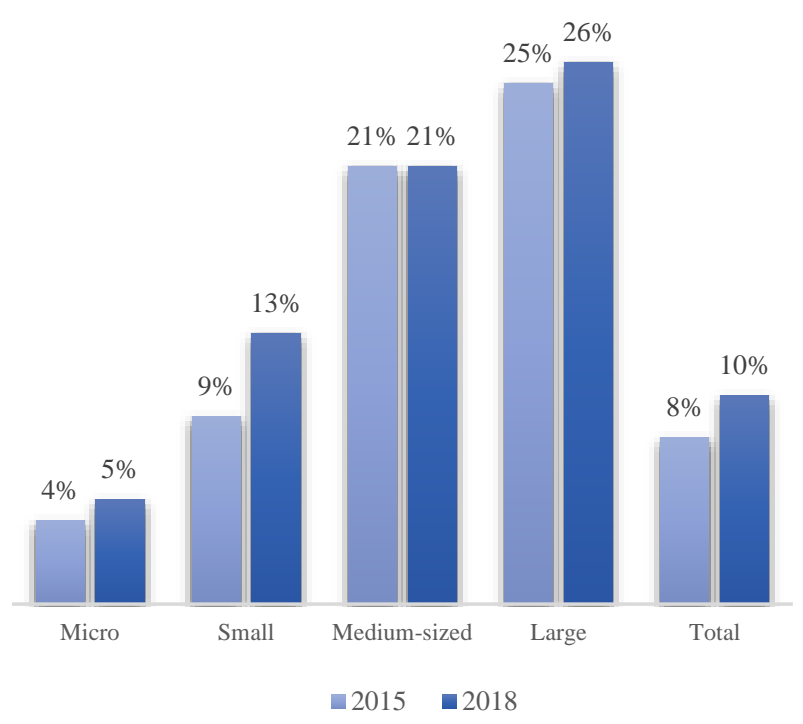

Graph 12 Companies that use financial leasing. Source: ENAFIN 2018, CNBV (2019).

\section{Conclusions}

MSMEs are recognized as an essential component in the social development and economic growth of Latin American countries because they are great contributors to the national GDP and because they are the main source of jobs, they generate an average of $61 \%$ of jobs. In Mexico, MSMEs create approximately $70 \%$ of jobs and contribute around 35\% of GDP. In general, in any country in Latin America the proportion of smaller companies that use bank financing is lower than that of large companies, this situation originates because banks require higher guarantees from MSMEs than from large companies at the moment granting credits (Ferraz and Ramos, 2018).

Despite the efforts made in Mexico, the proportion of companies that have access to bank financing is low, compared to most countries in the world, and the companies that present the most this restriction are microenterprises.
In Mexico, the lack of financing is one of the main problems that hinder the economic growth of MSMEs, which causes high corporate mortality. Micro-enterprises considered the lack of credit as the most important problem for which their businesses do not grow.

In general, MSMEs that obtain financing from the private sector must pay higher interest rates than large companies. According to Banco de México, the average interest rate in 2017 was $7.9 \%$ for large companies, 10.8 for mediumsized companies, 12.2 for small companies, and 14.5 for micro-companies.

For this reason, MSMEs that have never requested or had financing since the beginning of their operations pointed out as the main limitation of access to credit, the "high interest" with $53.5 \%$, this situation confirms that the high cost of financing is one of the main obstacles to not accessing external financing.

This context affects microenterprises much more because in 2018 only $14.6 \%$ of these companies had financing and the smaller the companies, it is more common that the lack of financing and its high cost hinder its development and economic growth

In this vein, the penetration of business financing in Mexico is a challenge that must be addressed urgently. Likewise, derived from the importance of MSMEs for the Mexican economy, it is necessary that the involved actors implement innovative public policies to strengthen the financial system and facilitate MSMEs access to external financing in the best conditions and thus improve their competitiveness and its economic growth.

\section{References}

Banco de Mexico. (2017). Indicadores Básicos de Créditos a las Pequeñas y Medianas Empresas (PYMES). Recuperado de http://www.banxico.org.mx/publicaciones-yprensa/rib-creditos-a-pymes/\%7B6F30DAE4E446-DE94-8A66-84CB2E2E0F54\%7D.pdf

Beck, T., y Demirgüc-Kunt, A. (2006). Small and medium-size enterprises: Access to finance as a growth constraint. Journal of Banking \& finance, 30(11), 2931-2943. https://doi.org/10.1016/j.jbankfin.2006.05.009 
Beck, T., Demirgüç-Kunt, A., y Honohan, P. (2009). Access to financial services: Measurement, impact, and policies. The World Bank Research Observer, 24(1), 119-145. Recuperado de https://openknowledge.worldbank.org/bitstream /handle/10986/4426/wbro_24_1_119.pdf?seque nce $=1$

Beck, T., Demirgüç-Kunt, A., Laeven, L., y Maksimovic, V. (2006). The determinants of financing obstacles. Journal of International Money and Finance, 25(6), 932-952. https://doi.org/10.1016/j.jimonfin.2006.07.005

Beck, T., Demirgüç- Kunt, A., y Maksimovic, V. (2005). Financial and legal constraints to growth: does firm size matter? The Journal of Finance, 60(1), 137-177. https://doi.org/10.1111/j.1540-

6261.2005.00727.x

Beck, T., Demirguc-Kunt, A., y Martínez-Pería, M. S. (2008). Bank financing for SMEs around the world: Drivers, obstacles, business models, and lending practices. The World Bank. Policy Research Working Paper 4785. Recuperado de https://openknowledge.worldbank.org/bitstream /handle/10986/6315/WPS4785.pdf

Beck, T., Demirgüç-Kunt, A., y Martínez-Pería, M. S. (2011). Bank financing for SMEs: Evidence across countries and bank ownership types. Journal of Financial Services Research, 39(1-2), 35-54. Recuperado de https://link.springer.com/article/10.1007/s10693 $-010-0085-4$

Berger, A. N., y Udell, G. F. (1998). The economics of small business finance: The roles of private equity and debt markets in the financial growth cycle. Journal of banking \& finance, 22(6-8), 613-673. https://doi.org/10.1016/S0378-4266(98)000387

Bermudez, N. y Bravo, A. (2019). Modelo Predictivo de los Determinantes del Cierre Empresarial de las MIPYMES en el Ecuador Período 2007-2016, X-Pendientes Económicos, 3(5), 78-93. Recuperado de https:/ojs.supercias.gob.ec , Xpedientes_Economicos $>$ article $>$ download
Castillo, V., Figal, L., Maffioli, A., y Ohaco, M. (2016). Asistencias técnicas y competitividad de las MiPyMes. Argentina: Banco Interamericano de Desarrollo.

Comisión Nacional Bancaria y de Valores, CNBV. (2016). Reporte Nacional de Inclusión Financiera 7. Recuperado de https://www.gob.mx/cnbv/acciones-yprogramas/divulgacion-de-inclusion-financiera26625

Comisión Nacional Bancaria y de Valores, CNBV. (2017). Reporte Nacional de Inclusión Financiera 8. Recuperado de https://www.gob.mx/cnbv/prensa/46-2017reporte-nacional-de-inclusion-financiera8 ?idiom $=$ es

Comisión Nacional Bancaria y de Valores, CNBV. (2019). Encuesta Nacional de Financiamiento de las Empresas (ENAFIN) Reporte de Resultados 2018. Recuperado de https://www.gob.mx/cms/uploads/attachment/fi le/498792/REPORTE_ENAFIN2018.pdf

De Mel, S., McKenzie, D. y Woodruff, C. (2008). Returns to capital in microenterprises: evidence from a field experiment. The Quarterly Journal of Economics, 123(4), 1329-1372. Recuperado https://www.jstor.org/stable/pdf/40506211.pdf? casa_token=siT1Ko5I188AAAAA:jOuvsh9Zfx rjBudH0cFxLBbfeqgdP-

jP20oipwkKjFvlavPB6vxM1H1oRTT39CQqq QaJZqgdE2HxIR69wKQI4SGUFvdVbULd_Q Yxi7fRGoZOFL0zMk41

Demirgüç-Kunt, A., Love, I., \& Maksimovic, V. (2006). Business environment and the incorporation decision. Journal of Banking \& Finance, 30(11), 2967-2993. https://doi.org/10.1016/j.jbankfin.2006.05.007

Dini, M. y Stumpo, G. (2018). Mipymes en América Latina: un frágil desempeño y nuevos desafíos para las políticas de fomento (Informe CEPAL - Serie Documentos de Proyectos). Recuperado de https://repositorio.cepal.org/bitstream/handle/11 362/44148/S1800707_es.pdf?sequence=1\&isA1 lowed=y 
Ferraz, J.C., y Ramos, L. (2018). Inclusión Financiera para la inserción productiva de las empresas de menor tamaño en América Latina. Innovaciones, factores determinantes $y$ prácticas de las instituciones financieras de desarrollo (Informe CEPAL - Serie Financiamiento para el Desarrollo No. 267). Recuperado de https://repositorio.cepal.org/bitstream/handle/11 362/44245/S1800956_es.pdf?sequence $=1 \&$ isAl lowed=y

Gómez, A., García, D. y Marín, S. (2009). Restricciones a la financiación de las PYME en México: una aproximación empírica. Análisis Económico, XXIV(57), 217-238. Recuperado de http://www.redalyc.org/articulo.oa?id=4131222 7011

Hernández-Sampieri, R. y Mendoza, C. P. (2018). Metodología de la investigación. Las rutas cuantitativa, cualitativa y mixta. Ciudad de México, México: McGraw-Hill Education.

Instituto Nacional de Estadística y Geografía, INEGI. (2015). Micro, Pequeña, Mediana y Gran Empresa. Estratificación de los Establecimientos. Censos Económicos 2014. Recuperado de https://www.inegi.org.mx/programas/ce/2014/d efault.html\#Documentacion

Instituto Nacional de Estadística y Geografía, INEGI. (2016). Encuesta Nacional sobre Productividad y Competitividad de las Micro, Pequeñas y Medianas Empresas (ENAPROCE) $2015 . \quad$ Recuperado de https://www.inegi.org.mx/contenidos/programa s/enaproce/2015/doc/ENAPROCE_15.pdf

Instituto Nacional de Estadística y Geografía, INEGI. (2019). Encuesta Nacional de Financiamiento de las Empresas 2018 (ENAFIN 2018). Recuperado de https://www.inegi.org.mx/contenidos/programa s/enafin/2018/doc/ENAFIN2018Pres.pdf

Kumar, S., Sureka, R., y Colombage, S. (2020). Capital structure of SMEs: a systematic literature review and bibliometric analysis. Management Review Quarterly, 70, 535-565. https://doi.org/10.1007/s11301-019-00175-4
León, E.L., y Saavedra, M.L. (2018). Fuentes de Financiamiento para las MIPYME en México. Ciencia Administrativa (1), 159-175. Recuperado de https://www.uv.mx/iiesca/files/2018/11/16CA2 01801.pdf

López-Gracia, J., y Sogorb-Mira, F. (2008). Testing trade-off and pecking order theories financing SMEs. Small Business Economics, 31(2), 117-136. https://doi.org/10.1007/s11187007-9088-4

McKenzie, D., y Woodruff, C. (2008). Experimental evidence on returns to capital and access to finance in Mexico. The World Bank Economic Review, 22(3), 457-482. https://doi.org/10.1093/wber/lhn017

Michaelas, N., Chittenden, F. y Poutziouris, P. (1999) Financial policy and capital structure choice in UK SMEs: Empirical evidence from company panel data. Small Business Economics, 12(2), 113-130.

https://doi.org/10.1023/A:1008010724051

Organización para la Cooperación y Desarrollo Económicos, OCDE. (2019). Financing SMEs and Entrepreneurs 2019: An OECD Scoreboard. Recuperado de https://www.oecdilibrary.org/industry-and-services/financingsmes-and-entrepreneurs-2019_fin_sme_ent2019-en

Watson, R., y Wilson, N. (2002). Small and medium size enterprise financing: A note on some of the empirical implications of a pecking order. Journal of Business Finance \& Accounting, 29(3- 4), 557-578. https://doi.org/10.1111/1468-5957.00443

Xiang, D., Worthington, A. C., y Higgs, H. (2015). Discouraged finance seekers: An analysis of Australian small and medium-sized enterprises. International Small Business Journal, 33(7), 689-707. https://doi.org/10.1177/0266242613516138 